\title{
EPISTEMOLOGICAL CONSTRUCTIVISM AND GEORGE ORWELL'S QUESTION: THE ETHICAL IMPLICATIONS OF AN INDEPENDENT REALITY
}

\author{
PAUL KINGSLEY
}

\begin{abstract}
:
Educational constructivists maintain that knowledge is constructed by students as they learn. Sometimes this involves a weakening of the epistemological claim that knowledge involves discovering facts about an independent reality. In the terminology of Immanuel Kant, we are claimed to have access to phenomena or appearances, but not to things in themselves. This approach is closely linked to Husserl's belief that objects must be "for" and "constituted by" some consciousness. All of these views place a great deal of emphasis on the notion of a disembodied consciousness that somehow constructs the world it perceives. They tend to weaken our belief in an independent world about which we can have objective knowledge. Is this a mere philosophical quibble of no practical importance? Does it really matter?

George Orwell, in his novel, 1984, introduces his unlikely hero, Winston Smith. He asks the question, "If both the past and the external world exist only in the mind, and if the mind itself is controllable what then?". Smith's tormentor, O'Brien, eventually supplies the answer. "But I tell you, Winston, that reality is not external. Reality exists in the human mind, and nowhere else...only in the mind of the Party, which is collective and immortal. Whatever the Party holds to be the truth, is truth." In short, the state engages in fabrications which are an extreme form of knowledge construction. Orwell outlines a situation where the distinction between constructing and discovering knowledge does matter. I shall argue that Kant, Husserl, and Wittgenstein conducted thought experiments with flawed research designs. They undermine the ethical role played by an independent reality in providing, in Iris Murdoch's words, something "which my consciousness cannot take over, swallow up, deny or make unreal".
\end{abstract}

\section{Keywords:}

constructivism, idealism, Ingarden, Orwell, Husserl, Kant, Peirce, von Glasersfeld, constructing reality, totalitarianism.

JEL Classification: 120,129

\section{Authors:}

PAUL KINGSLEY, University of Liverpool / Laureate Online Education, United Kingdom, Email: Paul.Kingsley@liverpool.ac.uk

\section{Citation:}

PAUL KINGSLEY (2015). Epistemological Constructivism and George Orwell's Question: the Ethical Implications of an Independent Reality. International Journal of Teaching and Education, Vol. III(4), 
pp. 33-53., 10.20472/TE.2015.3.4.004 


\section{Introduction}

Educational constructivists maintain that knowledge is constructed by students as they learn. Sometimes they are making a purely pedagogical point, referring to the way that students learn. More controversially, they are sometimes making a point about epistemology, making claims about the nature of knowledge. To know something that can be expressed in a proposition is to know something that is true; but this means that if we construct knowledge, we also construct the truth. There is, epistemologically, quite a difference between constructing and discovering knowledge.

Sometimes this involves a weakening of the epistemological claim that knowledge involves discovering facts about an independent reality. In the terminology of Immanuel Kant, we are claimed to have access to phenomena or appearances through experience, but not to things in themselves. This approach is closely linked to Husserl's belief that objects must be "for" and "constituted by" some consciousness, and to the early Wittgenstein's view that the self is not part of the world. All of these views place a great deal of emphasis on the notion of a disembodied consciousness that somehow constructs the world it perceives. They tend to weaken our belief in an independent world about which we can have objective knowledge. Is this a mere philosophical quibble of no practical importance? Does it really matter?

The later Wittgenstein stated that philosophy "leaves everything as it is", which may have given the impression that it is some kind of intellectual game with no practical significance (Wittgenstein, 1972, 121). That would be unfortunate, because it is clear that the philosophical beliefs that people hold can make them behave quite differently.

\section{Orwell and Philosophy}

George Orwell, in his novel, 1984, introduces his unlikely hero, Winston Smith. The character asks the question, "If both the past and the external world exist only in the mind, and if the mind itself is controllable what then?" (Orwell, 1992, p.106). For Winston Smith, struggling to survive in a totalitarian society, the question is not asked as part of an intellectual game. For him, the answer has significant consequences.

His tormentor and official of the ruling Party, O'Brien, eventually supplies the answer. "But I tell you, Winston, that reality is not external. Reality exists in the human mind, and nowhere else. Not in the individual mind, which can make mistakes, and in any case soon perishes: only in the mind of the Party, which is collective and immortal. Whatever the Party holds to be the truth, is truth. It is impossible to see reality except by looking through the eyes of the Party." (Orwell, 1992, p.314).

All the media is controlled by the state and the Party message is broadcast through the ever present telescreens. The Party sometimes finds it difficult or inconvenient to improve 
real conditions in society. It therefore rewrites history. Back issues of newspapers are amended. Those who have fallen out of favour are removed from the records. They become "unpersons" who do not exist and have never existed. Winston could remember his native Oceania being at war with Eastasia and in alliance with Eurasia. Now it was at war with Eurasia. "But that was merely a piece of furtive knowledge which he happened to possess because his memory was not satisfactorily under control. Officially the change of partners had never happened. Oceania was at war with Eurasia: therefore Oceania had always been at war with Eurasia." (Orwell, 1992, p.44).

For the Party, the changing of the contents of people's minds and the "correction" of their memories is a viable alternative to telling the truth.

This troubles Winston Smith. "If the Party could thrust its hand into the past and say of this or that event, IT NEVER HAPPENED—that, surely, was more terrifying than mere torture and death?

The Party said that Oceania had never been in alliance with Eurasia. He, Winston Smith, knew that Oceania had been in alliance with Eurasia as short a time as four years ago. But where did that knowledge exist? Only in his own consciousness, which in any case must soon be annihilated. And if all others accepted the lie which the Party imposed - if all records told the same tale-then the lie passed into history and became truth. 'Who controls the past,' ran the Party slogan, 'controls the future: who controls the present controls the past.' And yet the past, though of its nature alterable, never had been altered. Whatever was true now was true from everlasting to everlasting. It was quite simple. All that was needed was an unending series of victories over your own memory. 'Reality control', they called it: in Newspeak, 'doublethink'." (Orwell, 1992, p.44-45).

This philosophical concern with the nature of truth and reality is an important, but possibly neglected, theme in Orwell's 1984. The society he describes is an extreme example of a constructed world. Reality exists only in the mind and can be changed simply by encouraging people to think different thoughts. Reality is something that is defined by the Party rather than something that is discovered.

What we can say is that the Party's philosophical views about truth and the nature of reality are associated with a different way of behaving in the world. Orwell's powerful example should therefore convince us that the question of whether we construct or discover knowledge is not a trivial issue. It can have far reaching consequences.

\section{Reality: The Ethical Dimension}

Iris Murdoch has given us this thoughtful insight into the relationship between reality and ethics: 
"If I am learning, for instance, Russian, I am confronted by an authoritative structure which commands my respect. The task is difficult and the goal is difficult and perhaps never entirely attainable. My work is a progressive revelation of something which exists independently of me. Attention is rewarded by a knowledge of reality. Love of Russian leads me away from myself towards something alien to me, something which my consciousness cannot take over, swallow up, deny or make unreal. The honesty and humility of the student - not to pretend to know what one does not know - is the preparation for the honesty and humility of the scholar who does not even feel tempted to suppress the fact which damns his theory." (Murdoch, 1971, p.87).

The brute facts of reality, "which my consciousness cannot take over, swallow up, deny or make unreal", place limits on our selfish ambitions. If we see reality in this way, we are less likely to see ourselves as creators of the world, able to manipulate perceptions to comply with our wishes. It creates a respect for a truth which is not just what we want it to be.

In the society which Orwell outlines there are no brute facts which place limits on a totalitarian government. It is the possible existence of such facts, supported by firm evidence, that Winston Smith sees as a radical threat to the Party.

"Sometimes, indeed, you could put your finger on a definite lie. It was not true, for example, as was claimed in the Party history books, that the Party had invented aeroplanes. He remembered aeroplanes since his earliest childhood. But you could prove nothing. There was never any evidence. Just once in his whole life he had held in his hands unmistakable documentary proof of the falsification of an historical fact." (Orwell, 1992, p.38-39)

\section{$4 \quad$ The Disembodied Subject}

\subsection{The Early Wittgenstein}

In the Tractatus, his earliest published work, Wittgenstein provides us with these thoughts:

"5.632 The subject does not belong to the world: rather, it is a limit of the world... 5.641 The philosophical self is not the human being, not the human body, or the human soul, with which psychology deals, but rather the metaphysical subject, the limit of the world not a part of it." (Wittgenstein, 1974).

Now it seems that there are certain particular circumstances in which people may feel that they are subjects which are not objects located in the world. They may feel that the self is on the outside looking in, dictating the limits which the world can have. But this egocentric and detached attitude can only be maintained in certain unusual circumstances. 
We can picture Wittgenstein in his rooms at Cambridge in quiet contemplation on a pleasant summer's day. He withdraws within himself until it seems that he is outside the world looking in. A cricket ball flies in through the window and hits him on the head. At this moment he does not feel that he is not part of the world. He is an object which has come into painful contact with another object.

It may help us to see what the problem is here if we introduce the concept of an experiment. Immanuel Kant believed that he was engaged in an "experiment of pure reason" in thinking about the relationship between the self and the world (Kant, 1929, p.24). If it is indeed thought of as an experiment, then the experimental design can be scrutinised. Some experiments can produce artefacts.

"In experimental science, the expression 'artifact' is sometimes used to refer to experimental results which are not manifestations of the natural phenomena under investigation, but are due to the particular experimental arrangement, and hence indirectly to human agency." (Hilpinen, 2011).

Consider these different experimental settings.

a. The philosopher sits in quiet contemplation. He or she is not interacting with the world. The body is inactive. No-one else is present. The philosopher concentrates on visual experience of static objects. He or she is quite capable of forgetting that he or she has a body at all.

b. The philosopher is in the middle of a riot. There are stones and bricks flying in his or her direction. There is someone with a baseball bat intent on splitting his or her skull. The heat of a nearby burning car is intense. The screams and cries of hatred are terrifying. His or her nostrils are filled with the pungent smell of burning tyres. A companion's voice is shouting at him or her to run.

It is highly likely that the experimental setting will influence the conclusions that are drawn about the nature of the self. The philosopher in the riot, just like the Wittgenstein who was hit by the cricket ball, is not in the least likely to believe that the self is something that does not have a body. The self that is sitting outside the world looking in disappears like a mirage. The self caught up in the riot is right in the middle of the world, interacting with it. This philosopher is a vulnerable object, being threatened by other objects. Any notions that the self is disembodied have been swept away in the face of the experimental data.

Unfortunately, philosophers disproportionately concentrate on the first kind of experimental setting. No blame should perhaps be levelled at a philosopher who likes peace and quiet in which to do his or her philosophising. The problem arises when his or her thinking concentrates only on solitary, introverted scenarios, and ignores riots. This encourages a kind of forgetfulness. In drifting off inside his or her own mind, the philosopher is in danger of excluding huge amounts of data. The philosopher forgets that 
he or she has a body. Experimental results therefore become artefacts of the experimental setting.

\subsection{Kant}

The problem therefore, is that what the early Wittgenstein called "the philosophical self" and "the metaphysical subject" is just a partial and distorted version of what a self is. It becomes even more of a problem if this subject that is not an object is seen as somehow more real or more fundamental than the body with which it is linked. This is essentially the viewpoint adopted by Kant. For Kant, the self is not (at least in part) an object located in space. The self is identified with the thinking subject.

All objects located in space are presented in experience to this thinking subject as appearances. The self cannot get beyond these appearances to what Kant called things in themselves (things as they are outside our experience of them). We are effectively imprisoned within the circle of our experience. At this point Kant is very close to the idealism of someone like Berkeley, who believed all physical objects are just ideas in someone's mind.

Now this is unfortunate for Kant, because he specifically claims to be refuting idealism. Kant would like to think that human beings come into contact with something beyond their experience. These are things in themselves.

"...though we cannot know these objects as things in themselves, we must yet be in position at least to think them as things in themselves; otherwise we should be landed in the absurd conclusion that there can be appearance without anything that appears." (Kant, 1929, p.27)

But, of course, Kant has no reason at all for believing that there are things in themselves beyond the appearances to which we have access in perceptual experience. His unusual method of approaching the problem means that he will always be in ignorance about the existence of things in themselves. Kant believed that he was developing something called transcendental idealism, which would be quite different from the idealism of Berkeley. However, unable to say anything about things in themselves, he finds that his approach looks extremely similar to classical idealism.

Kant seems to acknowledge this problem in this passage:

"When, therefore, we say that the senses represent objects as they appear, and the understanding objects as they are, the latter statement is to be taken, not in the transcendental, but in the merely empirical meaning of the terms, namely as meaning that the objects must be represented as objects of experience, that is, as appearances in thoroughgoing interconnection with one another, and not as they may be apart from their relation to possible experience (and consequently to any senses), as objects of the pure 
understanding. Such objects of pure understanding will always remain unknown to us; we can never even know whether such a transcendental or exceptional knowledge is possible under any conditions - at least not if it is to be the same kind of knowledge as that which stands under our ordinary categories." (Kant, 1929, p.274)

What Kant has not done is to highlight some interesting contingent fact about the way we encounter appearances and things in themselves. What he has done is to define things in themselves as to be completely beyond our grasp. It is logically impossible to have knowledge about things in themselves. It is impossible in all possible worlds. It is impossible by virtue of the meaning of the words.

In short, Kant's conclusion is an artefact of aspects of his experimental design. He has rigged the experiment so that it can have only one result. A different definition which was more in line with common usage, would have avoided the problem.

The later Wittgenstein may have had something to say about this. Let us take a look at the full quotation which refers to philosophy leaving the world as it is.

"124. Philosophy may in no way interfere with the actual use of language; it can in the end only describe it. For it cannot give it any foundation either. It leaves everything as it is." (Wittgenstein, 1972, 124)

The problem for all kinds of idealism is that our actual use of language is unashamedly realist. We do believe that we are in touch with objects outside our experience. This is probably because most of us see ourselves as physical objects interacting with other physical objects, and not mainly as disembodied minds.

It would perhaps be going too far to say that philosophers should never interfere with the actual use of language. If there are compelling reasons to change ways of speaking that are misleading, then we should do so, but the burden of proof is very much on those who want to make the change. Ironically, for those who wish to mix their pragmatism with some form of idealism in asserting that what is true is what works, realist everyday language seems to work rather well.

Kant's attempt to redefine terms produces no improvements. He just defines himself into a blind alley.

\subsection{Husserl}

Experimental bias in favour of the disembodied mind that is a subject, but not an object, can also be found in parts of Husserl's work. It must be said that Husserl is something of a mystery. He said different things at different times in his life. Rather inconveniently, he did not usually repudiate his former views in an explicit way. We are therefore left with incompatible analyses and endless arguments about what Husserl really meant. This 
author does not intend to try to untangle that web. Instead this paper will concentrate on examining some of Husserl's views which have influenced those who construct unusual experimental designs which give priority to the disembodied mind.

At one point in his life, Husserl too was arguing that he had escaped from idealism by promoting transcendental idealism. A physical object was not identified with his current perceptual experience of it. The object transcended that, and included past and future experiences. Some of his colleagues such as Stein, Ingarden and Daubert believed that he had not escaped from that snare.

In his early work, Husserl placed the emphasis on studying the phenomena that appeared in his consciousness. This was seen as broadly neutral on the question of realism-idealism (Zahavi, 2003, p.40). Later Husserl took what has sometimes been called his "transcendental turn". It involved using the epoché. In English, this is usually described as involving a process of "bracketing" or ignoring the existence or otherwise of the objects that appear in consciousness (Smith, 2003, p.16). The natural attitude which most people have in believing in the existence of the world is suspended during the philosophical investigation. Husserl studied experience as it presented itself to a thinking ego (Calcagno, 2007, p.15).

Crucially, Husserl believed that the conscious subject had a quite different status from the objects that were presented to it. The existence of the thinking subject could not be doubted (Smith, 2003, p.18). The inevitable happened. Because the experiment was set up in such a way as to give a privileged status to the ego, objects in the physical world were studied only as they were "for" or "constituted by" consciousness. They are nothing more than that. Pure consciousness seems to be "outside the world and opposed to it" (Ingarden, 1975, p.31).

Once the experiment had been biased in this way, there was no way back. It could be argued that Husserl always intended to eventually remove the bracketing from around the objects of consciousness. When this is done, however, they are by now completely dependent on consciousness for their existence. It was difficult for Husserl "to avoid being committed in advance to the idealist solution" (Ingarden, 1975, p.38).

In Husserl there is a very similar bias in favour of the disembodied mind that is displayed in Kant. Later, Husserl,was to see, under the influence of Edith Stein, that the existence of other people could only be inferred by thinking of them as having bodies. Without this concept of the embodied mind or "the soul-bodied consciously experiencing man" (Ingarden, 1975, p.66-67), Husserl was in danger of being committed to solipsism (Zahavi, 2003, p.141). Husserl tried to talk about consciousness in general, but because of the way he perceived these issues, he had no way of accessing any consciousness other than his own. He could say things about his own consciousness but not that of other people's. They would just be "for" and "constituted by" his consciousness. 
The issues raised by Husserl are philosophically complex, but the popular appeal of his view of consciousness among those who think in terms of constructing reality is not based on such matters of detail. They are perhaps more likely to be attracted by a number of general ideas or ways of thinking about the problems involved. It will therefore be useful to look at some alternatives to these ways of viewing things.

\subsection{Criticisms of Husserl and Kant}

Husserl probably had difficulty in getting his head around the idea that a physical object could be out there in the world as well "in his mind" during an act of perception. He was also obsessed with the search for some certain foundation on which to base experience. Husserl thought he had found that in the conscious self. In fact, every time he said something about this conscious self, he was stating something that was fallible.

Johannes Daubert thought that Husserl's way of envisaging consciousness was part of the problem. Sometimes consciousness seems to be like a cinema in which Husserl is imprisoned all alone. He can see and analyse the things on the screen, but he really has no idea how they got there. There is no possible escape from the cinema.

Daubert suggested that the difficulty could be remedied somewhat by thinking of consciousness not as an object but as a function. To use another analogy, consciousness is not a box which contains experiences. Daubert suggests "that in which reality shows itself is nothing existing by itself, but only a function directed towards reality" (Schuhmann and Smith, 1985, p.769). It is always consciousness of something. "Consciousness functions in a normal way only when it 'hits' an object....It is in imaginative or hypothetical thinking, in neutralization or reduction, when consciousness seeks to withdraw in different ways from contact with reality, that it acquires a pseudobeing of its own." (ibid, p.772). The danger is that "...the pure ego acquires the status of an absolute substance, reality that of a mere dependent accident" (ibid, p.773). "Consciousness is not a real annex to bodies, not a reality superadded to perceiving or perceived real things, it is a relational structure obtaining where animate bodies and things in the world come into contact with each other in specific sorts of ways" (ibid, p.778). "Consciousness of a thing is not itself a thing...I insure my house against fire, not my consciousness of the house...I do not insure possibilities of perception, and it is not possibilities of perception that burn down." (ibid, p.786). Then, in linking to Iris Mrdoch's point, "The object in reality 'assigns certain limits' to our freedom of grasping it in judgements or in concepts...' I experience the autonomy with which [the real object] accepts one determination and rejects another'" (ibid, p.789).

So what is the link between these philosophical arguments and an intellectual climate in which people like Orwell's O'Brien flourish? 
One of the requirements we have of any theory is that it accounts for or explains the known facts. One of the difficulties with all forms of idealism, transcendental or not, is that they fail to explain why the sequence of my conscious experiences is the way it is. A realist would say that the reason that 100 students see and hear the teacher's lecture is because there really is a teacher there delivering a lecture, and this does not depend on my consciousness constructing or constituting that reality. The reason that all 100 students see and hear roughly the same thing is because that is what the teacher actually said outside of each consciousness. If there is a dispute, a video and audio recording can be produced to settle the argument.

Idealists, who probably behave as realists for most of their lives, would like to say something similar. However, if the teacher is an object that exists for, and is constituted by Husserl's consciousness, and he does not believe he can get outside that consciousness, he has some difficulty. Husserl can compare one experience with another, but he cannot make use of a teacher outside his consciousness to explain the experience he is actually having. Similarly, for Kant. This philosopher may claim that the teacher is as real as can be, but all he has access to is information within Kant's subjective experience because, by definition, he has no way of knowing anything about things in themselves. Because other people are, for Kant, things in themselves to which he has no access, they cannot be of assistance in explaining why the sequence of his experience, containing as it does seeming interactions with other people, has the precise order and content that it does.

What both Husserl and Kant need is some causal interaction between the self and objects independent of the self. If the philosopher is not tempted to think of his or her self as primarily a disembodied mind, there is no problem. Where the self is viewed as a disembodied mind which has contact only with the contents of its own circle of experience, the contents and sequence of that experience are, as long as the idealist remains committed to his or her philosophical assumptions, something of a mystery.

This creates a knowledge vacuum. As soon as we abandon the idea of a brute reality being the cause of a large number of our perceptual experiences, we start looking for an alternative. One of the most popular options is that we construct the world based on our goals and values. Why the 100 students see and hear roughly the same thing is still something of a mystery, because they have clearly not conferred beforehand to construct what the teacher was going to say within the confines of their own minds. Nor did they obviously confer after the event to decide what they wanted the teacher to say without any reference to what a real teacher, existing outside the consciousness of each student, actually said in a particular place at a particular time.

However the creation of the vacuum constitutes progress for people like O'Brien. He certainly does not want to be faced by the phenomenon outlined by Daubert. That 
philosopher felt that the object in perception assigns certain limits to our freedom to make judgements about it. There is some room for interpretation, but there are limits to our freedom to interpret the object. "I experience the autonomy with which [the real object] accepts one determination and rejects another" (Schuhmann and Smith, 1985, p.789). Brute facts often restrict our wilder imaginings in subtle ways.

O'Brien needs to remove these restrictions in order to open the way for the truth to be whatever the Party says it is. He needs a more malleable reality. In his society the individual citizen has the obligation to exercise what Orwell calls reality control. Experience must be re-interpreted in the light of what the Party wants people to believe. In some cases the past is rewritten. That which would be inconvenient never happened. All contrary evidence is destroyed. The truth is restricted to what is in in people's heads, and the Party can control what people think through constant propaganda and ruthless surveillance.

Now one popular extension of the view of Kant and Husserl about the non-existing relationship between consciousness and an external world is to say that truth is a matter of inter-subjectivity. We all check with each other's experiences to decide what is true. It is, of course, not quite consistent with Kant and Husserl's assumptions. Neither can really escape from solipsism, the view that the self is all that can be known to exist. Kant could not get beyond his own self and its experiences, as everything else would consist of things in themselves, about which we can know nothing. Husserl could not do so until he later took seriously the fact that the human body was a very important part of the self. Once he admitted that, then he escaped from an idealism that had placed him in a solipsistic prison.

Let us set aside Kant and Husserl's very restrictive assumptions and assume that it makes sense to operate in the spirit, but not to the letter, of their teachings. Pragmatists might be keen on some form of inter-subjectivity. O'Brien would be happy enough with this. His Party can control what people think. He can therefore create an inter-subjective consensus. People like Winston Smith can be told that he is in a small minority and must therefore be wrong. Where truth is what people agree it to be, then small minorities can never be guardians of the truth.

\subsection{Peirce}

The American pragmatist, Charles Peirce, saw the problem. He tried to distinguish himself from other idealist-orientated pragmatists by describing himself as a pragmaticist. Peirce made a key distinction between a definition of truth and a pragmatic means of pursuing it. He provides "a pragmatic elucidation of a concept - an account of the role the concept plays in practical endeavours" (Misak, 2004, p.viii). 
We may well consult others in gathering evidence that will lead us to true beliefs, but that is not to say that the views of others, even if held by an overwhelming majority of citizens, are, by definition, what is true. They could all be wrong. It is indeed possible for a single person like Winston Smith to know that something is a lie even if no-one else does.

Peirce said quite unambiguously that he thought that knowledge consisted of justified true belief:

"Plato is quite right in saying that a true belief is not necessarily knowledge. A man may be willing to stake his life upon the truth of a doctrine which was instilled into his mind before his earliest memories without knowing at all why it is worthy of credence; and while such a faith might just as easily be attached to a gross superstition as to a noble truth, it may, by good luck, happen to be perfectly true. But can he be said to know it? By no means: to render the word knowledge applicable to his belief, he must not only believe it, but must know, I will not say, with the ancients, the rationale of the real fact, as a reality, -- but must know what justifies the belief, and just WHY and HOW the justification is sufficient." (Peirce, 1958, 7.49)

However, he needed some practical means of supplying the justification for beliefs. He therefore stressed the importance of a process of inquiry, conducted according to rational methods, in leading us to the truth. In saying that the truth is what we would have at the end of all inquiry, Peirce perhaps pushed the point too far, but his philosophy has introduced an air of realism to the debate about pragmatism.

Important for Peirce is our ability to be surprised during scientific inquiry.

"A man cannot startle himself by jumping up with an exclamation of Boo! Nor could the perceptual judgment have represented anything so out of nature. The perceptual judgment, then, can only be that it is the Non-Ego, something over against the Ego and bearing it down, is what has surprised him." (Peirce, 1935, 5.58)

\subsection{Dealing With Surprises}

Kant and Husserl both have difficulties accounting for surprises. The person who believes that we construct reality, in any meaningful sense, has even more problems. If the guiding principle of what we construct (or possibly reconstruct) is not what is actually there, then the obvious alternative is that the world is constructed according to our goals and purposes. If this is anything but an amusing metaphor, it becomes surprising that we are surprised by things. If the world is our creation, formed according to our wishes, then why are we ever surprised? The most obvious answer is that there is a world independent of our consciousness, full of brute facts that we are constantly compelled to accept, and which often surprise us. 
O'Brien clearly does not like surprises, but he is different. He and his Party colleagues first see the truth and then distort and suppress it, so that others will not see what they have seen. This points to the fact that perception is an ethically governed enterprise. Daubert felt that the objects we are perceiving assign certain limits to the judgements we make about them. There is some room for interpretation, but if we go beyond the limits which an external reality imposes on us, we distort the truth. We can select parts of the world to study depending on what we want to achieve, but if we suppress some of the relevant facts during inquiry, because they do not suit us, we do not behave ethically.

Roman Ingarden, a colleague of Husserl's, wrote about objects which are existentially autonomous (Mitscherling, 1997, p.104). In passive perception, the perceiving subject is struck by the "otherness" or "foreignness" of the object. It is not our creation (Mitscherling, 1997, p.101).

Peirce also highlights the issue in writing about surprise.

"Thus it is that all knowledge begins by the discovery that there has been an erroneous expectation of which we had before hardly been conscious. Each branch of science begins with a new phenomenon which violates a sort of negative subconscious expectation" (Peirce, 1958, 7.188)

"Any surprise involves a resistance to accepting the fact. One rubs one's eyes, as Shaler used to do, determined not to admit the observation until it is plain one will be compelled to do so." (Peirce, 1958, 8.315)

We often get unpleasant surprises. We expect one thing to happen and get another. This may lead to our being disappointed. Perhaps we don't want to accept the truth. The first step towards behaving ethically is to accept the authority of brute facts. They are not our constructions or creations. They may not be what we wanted. We should, however, resist the temptation to act as if we were creators of the world. Some people like O'Brien would insist that the surprise must indicate that we have constructed our experiences inefficiently. Things cannot be different from our expectations in a world which we constructed in our minds according to our own desires.

The resistance to accepting the facts, which Peirce warned about, can be extreme. O'Brien would substitute the Party's version of events to remove all nasty surprises. Before long, through the use of state propaganda and repression, the contents of people's minds would be changed to be in accord with the views of the Party. Officially, no nasty surprise ever happened.

It is certainly strange that various forms of idealism cannot explain the sequence of perceptual events presented to our conscious minds. It is mildly alarming that they leave open the door for people like O'Brien to reject the authority of brute facts so that reality can be redefined in the interests of totalitarian movements. But what can we say to deter 
students from believing that they are a disembodied mind which constructs the world according to their wishes without having to worry about brute facts placing limitations on their wilder ambitions?

\subsection{Taking the Body Seriously}

The first thing we can do is to take the body seriously. Our visual perceptual experiences are governed by the physical location of our bodies in space. The person who is struck in the eye with a cricket ball will also see that the quality of his or her visual perception is dictated by the state of their eyes. In our wilder speculations about the Cartesian disembodied self, it is easy to forget such simple realities. Our body is not some add on which makes an entrance as an appearance in the conscious mind. If we acknowledge that the body is an important part of the self, a lot of our problems disappear. We see ourselves, at least in part, as an object which interacts with other objects. How does that help?

Let us counterbalance talk about inter-subjectivity with some examples of inter-objectivity. Increasingly inanimate devices can detect the presence of other objects or the state that objects are in. Sensors can detect the temperature in rooms, and send a message to a computer so that it can turn a heating system on or off or adjust its output up or down. Burglar alarms can be set off by stray cricket balls crashing through closed windows. The smoke alarm detects smoke and sets off the sprinkler system. The toy robot detects that it is about to run into a chair and navigates around it.

In each of these cases, objects with no consciousness detect the presence of other objects or states of affairs and execute appropriate behaviour. We do not agonize about whether these devices have encountered the thing in itself or simply an appearance of an object. We are not tempted to believe that what is detected exists only for, and is constituted by, the device which detects it. The ways that objects apprehend each other is not a mystery to us.

There is a core of truth in pragmatism. It often makes sense to ask a number of people what happened and to accept their consensus view as the truth. In the absence of evidence of collusion to concoct a story for some underhand purpose, we think this is a reasonable thing to do. Why? Because we think that the most likely explanation of a number of people independently offering the same account is that this is what actually happened.

It is, however, just one form of evidence that we can accept. There could be footage from security cameras, fingerprints, DNA, gunshot residue, the checking of timelines against alibis, bank statements, tyre tracks, a smashed watch which stopped at a particular time, toxicology reports, records of weather conditions, threatening letters, mobile phone records, and statistical probability calculations. We get evidence from objects as well as 
people, so we should not get too hung up on the idea of people needing to agree on the experiences they have.

Part of the problem with Kant and Husserl's Cartesian view of the self is that there is a failure of the imagination. These philosophers simply could not get their head round the idea that a chair could at one and the same time be "in the mind" and out there is the physical world. The world was therefore absorbed as part of the mind. If we take the body seriously, we can acknowledge that perception is based on an interaction between our bodies and the world around them. It is not baffling at all to conceive of how a chair might be at one of the same time seen by us (by opening our eyes) and be six feet away from us in the world outside our self. Physical objects which interact with other physical objects are much easier to get our head round. Our imagination is not overstretched.

The later Husserl did begin to take the body seriously (Smith, 2003, p.230-232). The body is very much present in experience, providing a series of phenomenal experiences that really should have been described as part of a phenomenological experiment. The chair appears in experience as six feet away from us, but the image is a little blurred because we have each been hit in the eye with a cricket ball. It was only a flawed experimental design which excluded these phenomena from consideration.

Merleau-Ponty tended to take a little more account of the body.

"...Merleau-Ponty appreciates the essentially incorporated structure of perception in a way that Husserl does not. For Merleau-Ponty, that is, the body plays a constitutive role in experience precisely by grounding, making possible, and yet remaining peripheral in the horizons of our perceptual awareness" (Carman, 1999, p.208).

More recent phenomenologists such as Shaun Gallagher have taken this a step further. Husserl at one stage got himself in such a tangle that he came dangerously close to saying that consciousness was needed to keep physical objects in existence (Smith, 2003, p.179). Gallagher points out that we are often capable of interacting with objects without their being present in consciousness.

"In the experience of driving, the automobile can seem to be an extension of the body the car's movements are easily and often unattentively under one's control. Thus, an experienced driver does not need to think about or be explicitly attentive to the details of driving or the car's movements. In some instances, for example, one can arrive at one's destination without a recollection of the actual details of the drive - the driving body has been on automatic pilot so to speak." (Gallagher, 2005, p.58)

In more recent years we have perhaps learned not to place too much emphasis on what is happening in the consciousness. Our bodies can do quite a lot without a film showing in the cinema of our mind. 


\subsection{Von Glasersfeld}

It may at first seem implausible that an excessive philosophical emphasis on the self as a disembodied mind could actually filter through into educational theory. but indeed it has. By looking at some of the ideas of the constructivist, Ernst von Glasersfeld, we can see how philosophy influences life.

Von Glasersfeld quotes Giambattista Vico approvingly.

"Man cannot know the things that are in the world because their component elements lie outside man's mind, and man, therefore has no access to them and cannot use them to build up true knowledge." (Von Glasersfeld, 2007, p.23)

If that were true then Vico could have no knowledge of other people. Acknowledging the importance of his body would make the task much easier. Von Glaserfeld also borrows Vico's idea that "man can know only what he constructs out of elements of his own experience" (Von Glasersfeld, 2007,, p.24). He develops this idea further by saying "objectivity arises when concepts, relations and operations that I have found to be viable in the management of my own experience, turn out to be viable also when I attribute them to the models of Others which I construct to manage my interactions with them" (Von Glasersfeld, 2007, p.28).

Viability or "what works" is an interesting idea that makes most sense if we are talking about what we are trying to achieve.

"Cognitive organisms...become goal-directed in that they will tend to repeat experiences they like and to avoid the ones they dislike... One kind of knowledge, then, is knowledge of what has worked in the past...Knowledge, from this perspective, must not be characterized as a 'picture of the world'. It does not reflect the world at all - it reflects what one can and what one cannot do." (Von Glasersfeld, 2007, p.33)

There are two problems here. There is the classic idealist problem of not being able to explain why we have the experiences we do have. Experience is something that happens to us, but we don't know why because we cannot get outside the circle of our experience. "I see a chair" is the result we are left with after some alleged construction takes place, but we cannot explain the experience in terms of there actually being a chair present as the reason why we have this particular experience at this moment.

The other problem is with the substitution of the concept of viability for that of truth. Orwell gives us no reason to believe that the society he outlines is not viable. The idea that what is true is what the Party says is true is actually working quite well. There are people like Winston Smith and his girlfriend, Julia, who are temporary irritants, but as we know from the story, they are eventually brought into line. 
The concept of viability is extremely broad and is capable of embracing things which are quite false, but which serve the dominant interests of society. Through what Orwell calls reality control, individuals can be trained to believe just what it is convenient for them to believe. O'Brien's totalitarian society works.

Von Glasersfeld thinks that scientific knowledge "provides more or less reliable ways of dealing with experience - and dealing with experience means to be more or less successful in the pursuit of one's goals" (Von Glasersfeld, 2007, p.36). O'Brien could have advised him that the easiest way of achieving such success is to construct reality in such a way that outcomes are always successful. If there are no brute facts to limit our wilder ambitions, then educating people to see the right things is the most efficient way to seem to be consistently successful.

Von Glasersfeld certainly sees the problem and desperately tries to save the day:

"It is not the case that 'anything goes' - and it is precisely through its obstructions that ontological 'reality' manifests itself: by impeding some of our actions and thwarting some of our efforts." (Von Glasersfeld, 2007, p.36)

This looks as though brute facts are being allowed to limit the pursuit of our goals, but alas, von Glasersfeld cannot withstand O'Brien's logic. Experience is just something that occurs in our minds without any intimate relationship with objects outside our minds. He acknowledges this problem elsewhere.

"...the construction [of knowledge] is subject to constraints which separate what is viable from what is not, but the nature of the constraints is inaccessible to the constructing subject, because there is no way of telling whether a failure is due to a flaw in the constructive operating or an obstacle of the ontological world." (Von Glasersfeld, 2007, p.108).

O'Brien would advise him that in the society outlined by Orwell, they do not have problems with constraints or recalcitrant facts. They are suppressed and history is rewritten. The population can, to a large extent, be made to think that the Party's efforts have not been thwarted.

Von Glasersfeld's difficulty is that he is struggling to find a reason why O'Brien's approach is invalid. If the closest we can get to "truth" is viability and success, then O'Brien's strategy works just as well, if not better, by removing perceptions of failure. It is just as viable as respecting what realists call the truth. What von Glasersfeld needs is a way of saying that the world, as it is outside the individual self, can place legitimate constraints on what we experience, but he simply cannot find a way of achieving this.

The loss of an object of experience outside von Glasersfeld's mind leads to a loss of moral compass. If a realist distorts objective reality, this is ethically unacceptable. If there 
is no objective reality outside von Glasersfeld's mind, the moral offence disappears. There remains only what works in achieving his objectives with the minimum of perceived obstructions to his endeavours. O'Brien has many of the answers for achieving that.

Von Glasersfeld mounts a spirited rear-guard action on the ethical issue.

"As long as we cling to the notion that parts of our experience reflect an objective world that is independent of our knowing, we are not compelled to feel responsible for that world. When it would be uncomfortable, laborious, or painful to change certain things, we can simply escape by saying: There is nothing we can do, because that is how it is..." (Von Glasersfeld, 2007, p.108)

Of course, to say that this is how things are is not to say that they cannot be changed by appropriate courses of action. Indeed, an accurate assessment of where we are at the moment gives us an excellent start in working out a plan for change. However, most of the problems we encounter are not of our making. Acknowledging the reality that certain things present themselves to us as brute facts which we did not influence is nothing to be ashamed of.

Now we do have some responsibility for not ignoring key facts when viewing a scene. We should not distort reality by concentrating on only some relevant parts of the picture. Apart from that, there is something disturbing about claiming responsibility for the contents of our mind during perceptual experience, as if they were our own creation. O'Brien might well say that some perceptual experiences are undesirable and that citizens should use reality control to adjust what they see. Such citizens would indeed feel responsible for their undesirable experiences. They would try to change their experiences without changing the world. But where there is no objective reality, changing our experiences cannot be distinguished from changing the world. Reality is just a construction that serves our purposes.

In totalitarian societies, the pursuit of the truth is often replaced by the promotion of the dominant ideology. In a rather ironic turn of events, the realist phenomenologist, Roman Ingarden, was prevented from teaching for a number of years in Communist Poland on the grounds that he was an idealist. By this, the authorities meant that he did not seem to promote the kind of materialism approved by the state. His Philosophy Department at Jagiellonian University was replaced by a Department of the Basis of Marxism (Mitscherling, 1997, p.21).

\section{Conclusions}

Orwell's Winston Smith asked the question "If both the past and the external world exist only in the mind, and if the mind itself is controllable what then?". Well the answer from the Party is that there is no objective reality, and no brute facts to place a check on the totalitarian ambitions of people like O'Brien. Winston Smith once had in his hands 
irrefutable documentary evidence that the state had lied. He had seen a photograph in a copy of the Times showing three people who had fallen out of favour with the Party. They were pictured at a Party function at the time they were supposed to be on Eurasian soil betraying important military secrets. Their confessions were a lie (Orwell, 1992, p.81-82).

The evidence existed not just in his mind, but independent of himself and O'Brien, out there in the world. It had to be destroyed by the state because it posed such a threat. Hard facts that are not mere constructions but brute realities that are difficult to think out of existence are what totalitarian societies fear most. They prefer a world which they have constructed, one that can be manipulated to remove all awkward consequences.

A respect for an independent reality which we do not create or construct, is an important step in removing one source of temptation to suppress or violate the truth in the service of our own selfish ambitions. Kant and Husserl tried desperately to preseve this concept while conducting thought experiments which seemed to massively reduce its chances of survival. The research design of those experiments was flawed. People were left as prisoners within their own consciousness because of presuppositions which could only lead to one biased outcome. Because of thse flaws there was no possibility of arriving at anything "which my consciousness cannot take over, swallow up, deny or make unreal". By acknowledging that the disembodied consciousness is only a partial and misleading representation of the self, we are able to escape from a solipsistic prison. By taking the body seriously we can relate more naturally to the world as a physical body encountering other physical objects, some of which also have minds..

It would be rather unfortunate if a strange preoccupation of certain philosophers with selves as primarily disembodied minds were to open the door to the O'Briens of this world. This way lies danger. There is a problem with making dramatic statements which, on closer examination, turn out to be saying something trivial. The dramatic headline or philosophical sound bite is what does the damage. Perhaps we can bear this in mind when we are tempted to say that we construct knowledge or reality.

\section{References}

Calcagno, A. (2007). The Philosophy of Edith Stein. Pittsburgh, Pennsylvania: Duquesne University Press.

Carman, T. (1999) 'The Body in Husserl and Merleau-Ponty'. Philosophical Topics 27 (2), pp.205-226.

Gallagher, S. (2005). How the Body Shapes the Mind. Oxford, England: Oxford University Press.

Hilpinen, R. (2011). Artifact [Online]. Available from Stanford Encyclopedia of Philosophy, http://plato.stanford.edu/entries/artifact/ (Accessed: 7 August 2015).

Ingarden, R. (1975). On the Motives which led Husserl to Transcendental Idealism. The Hague, Netherlands: Martinus Nijhoff. 
Ingarden, R. (2013). Controversy over the Existence of the World, Volume 1. Frankfurt, Germany: Peter Lang.

Kant, I. (1929). Critique of Pure Reason. London, England: Macmillan Press.

Misak, C (2004). Truth and the End of Inquiry: a Peircean Account of Truth. Oxford, England: Oxford University Press.

Mitscherling, J. (1997). Roman Ingarden's Ontology and Aesthetics. Ottawa, Canada: University of Ottawa Press.

Murdoch, I. (1971). The Sovereignty of Good. London, England: Routledge.

Orwell. G. (1992). Nineteen Eighty-Four. London, England: Everyman's Library.

Peirce, C. (1935). Collected Papers of Charles Sanders Peirce, Volumes 5 and 6. Cambridge, Massachusetts: Belknap Press.

Peirce, C. (1958). Collected Papers of Charles Sanders Peirce, Volumes 7 and 8. Cambridge, Massachusetts: Belknap Press.

Schuhmann, K. and Smith, B. (1985) 'Against Idealism: Johannes Daubert vs. Husserl's Ideas I'. Review of Metaphysics 38 (4), June, pp.763-793.

Smith, A. (2003). Husserl and the Cartesian Meditations. London, England: Routledge.

Von Glasersfeld, E. (2007). Key Works in Radical Constructivism. Rotterdam, the Netherlands: Sense Publishers.

Wittgenstein, L. (1974). Tractatus Logico-Philosophicus. London, England: Routledge.

Wittgenstein, L. (1972). Philosophical Investigations. Oxford, England: Blackwell.

Zahavi, D. (2003). Husserl's Phenomenology. Stanford, California: Stanford University Press. 